\title{
Magnetic Mapping for Delineating Structures Favorable to Uranium Mineralization in Dhofar Region, Sultanate of Oman
}

\author{
N. Sundararajan ${ }^{1}$, B. Pracejus ${ }^{1}$, S. Al- Khirbash ${ }^{1}$, T. K Al- Hosni ${ }^{1}$, Alaeddin Ebrahimi ${ }^{1}$ and M. Al- Mushani ${ }^{2}$ \\ ${ }^{1}$ Department of Earth Science, College of Science, Sultan Qaboos University, Muscat, Sultante of Oman \\ ${ }^{2}$ Ministry of Commerce and Industry, Sultante of Oman
}

\section{Abstract}

The Proterozoic basement is a potential host for uranium mineralization and therefore the probability of occurrence of uranium is highly likely in the Dhofar region of southern Oman. The crystalline basement of the Salalah area (Dhofar, Sultanate of Oman) is the largest area of Proterozoic basement of the Arabian-Nubian Shield which outcrop in Oman. It is because, the most productive parts of the crust for uranium exploration and production in the world are in similarly aged i,e Proterozoic rocks. Further, the area is heavily faulted and some of these faults have already been identified as the place of uranium enrichment. Also, the fault systems must have acted as fluid conduits for circulating waters scooping up uranium from deeper formations and carrying it to higher levels along the fault plane and also distributing it near the surface. Random sampling of gamma ray spectroscopy has revealed a concentration of uranium as much as $30-35 \mathrm{ppm}$ which was substantiated by XRF analysis near the study area. And therefore, the interest lies in investigating the uranium mineralized subsurface structuers. Accordingly, total magnetic fields along eleven traverses were recorded at an approximate line interval of $20 \mathrm{~m}$ with a measurement interval of $10 \mathrm{~m}$ in the study area close to Yemen border. The acquired data was subjected to regional residual separation to decipher low frequency signals related to deep anomalies and also residual component to depict high frequency shallow seated small features. The computed amplitude of analytical signal indicates the precise spatial location of subsurface sources. Further, estimated depth to source based on Euler deconvolution (ED) and Fourier spectral analysis are found to be in the range of $<15 \mathrm{~m}->60 \mathrm{~m}$. The salient features of the analysis highlighting the outcome are presented.

\section{Introduction}

The oldest of all geophysical investigations began with the magnetic mapping as this technique is simple, efficient, and economical besides being reliable. It is widely used technique for locating both hidden ores and structures associated with mineral deposits as well as oil and gas [1,2]. Magnetic method is quite popular and are being used in the exploration $[3,4]$ to delineate subsurface structures such as faults, anticlines, synclines etc. $[5,6]$.

Normally the acquired magnetic data in any geophysical survey is the sum of magnetic fields produced by all underground sources. The subsurface targets of specific surveys are often small scale structures buried at shallow depths. The magnetic responses of these targets are embedded in a regional field that arises from magnetic sources that are usually larger or deeper than the targets or are located farther away. Fairly correct estimation and removal of the regional field from the initial field observations yields the residual field produced by the subsurface target. It may be noted that the qualitative interpretation of magnetic anomalies has to do something on studying the given magnetic map, profile or digital data to have a picture of the probable subsurface causes separating the effect of individual features on the basis of available geophysical and geological data and estimating the likely parameters of the bodies of interest from the corresponding residual [7]. Ramesh Babu et al. [8] have successfully applied magnetic method in association with VLF-EM technique in delineating uranium deposit in Proterozoic basins of Raigarh ore, India.

On the other hand, the quantitative interpretation is meant to compliment the qualitative method and provide useful estimates of the geometry, depth and magnetization of the magnetic sources $[9,10]$. Regional magnetic maps reflect the deeper part of data carrying less about shallower parts $[11,12]$, while the residual ground magnetic

\section{Publication History:}

Received: December 21, 2016

Accepted: February 18, 2017

Published: February 21, 2017

\section{Keywords:}

Total magnetic anomaly, Uranium deposits, Amplitude of analytic signal, Tilt derivate, Spectral analysis, Euler deconvolution map gives moderately low magnetic values which is an indicative of shallow subsurface geologic structures [13]. Yet another means of interpreting the magnetic anomalies is the Euler deconvolution of the total magnetic field and its spatial derivatives. Euler deconvolution has emerged as a powerful technique for automatically estimating the depth and the geometry of the buried magnetic sources $[14,15]$. This technique has become popular because no need of an apriori information about the source magnetization and special geological model as required for profiles [14] and gridded data [15].

The spectral analysis has the ability to filter out the noise from the data sans any loss of information during the process, and in general, operations are easier to perform in frequency domain [16]. Spectral analysis of magnetic anomalies ensures source parameters such as depth, dip, width etc in addition to basement depth [17]. Relatively a recent method developed by Salem et al. [18] for the interpretation of gridded magnetic data based on derivatives of the tilt angle, provides a simple linear equation, similar to the 3D Euler equation. This method estimates both the horizontal location and the depth of magnetic bodies, in the absence of any knowledge of about the nature of the sources structural index. However, using source-position estimates, the nature of the source can then be inferred. The method ensures

"Corresponding Author: Dr. Narasimman Sundararajan, Department of Earth Science, College of Science, Sultan Qaboos University, Muscat, Sultante of Oman; E-mail: visvid12@squ.edu.om

Citation: Sundararajan N, Pracejus B , Al- Khirbash S, Al- Hosni TK, Ebrahimi A et al. (2017) Magnetic Mapping for Delineating Structures Favorable to Uranium Mineralization in Dhofar Region, Sultanate of Oman. Int J Earth Environ Sci 2: 127. doi: https://doi.org/10.15344/2456-351X/2017/127

Copyright: () 2017 Sundararajan et al. This is an open-access article distributed under the terms of the Creative Commons Attribution License, which permits unrestricted use, distribution, and reproduction in any medium, provided the original author and source are credited. 
Citation: Sundararajan N, Pracejus B , Al- Khirbash S, Al- Hosni TK, Ebrahimi A, et al. (2017) Magnetic Mapping for Delineating Structures Favorable to Uranium Mineralization in Dhofar Region, Sultanate of Oman. Int J Earth Environ Sci 2: 127. doi: https://doi.org/10.15344/2456-351X/2017/127

Page 2 of 9

an adequate accuracy because it utilizes second order derivatives of the magnetic anomaly and is sensitive to the presence of noise in the acquired data [19].

The amplitude of the analytical signal or energy envelope [20] of magnetic anomalies is an important property which is independent of the direction of magnetization of the source [21]. A major advantage of using the analytic signal is to identify magnetic anomalies independent of remanence [22]. In specific, the amplitude of analytical signal is used in potential field data for precise spatial location of subsurface targets [23].

In this study, prior to magnetic survey, gamma ray spectroscopic measurements were made randomly as well as a grid along the traverses. Additionally, a G-859 mining magnetometer (Geomtrics) was used to investigate subsurface structure speculated as a mineralized hidden fault. Accordingly, as many as eleven profiles in varying length (due to hazardous terrain) along which measurements were made at an interval of $10 \mathrm{~m}$ in Dhofar region, close to Yemen border of Sultanate of Oman. After applying preliminary corrections, the regional map to illustrate deep anomalies and also the residual map to study near surface targets were obtained. The ED of the tilt derivative map has provided the depth to source location of the subsurface features. Finally power spectrum of the magnetic field data has been derived for a half space source and the structures that are deciphered to be lineaments. It may be interesting to note that all these quantitative methods of interpretation resulted the source parameters in close agreement to each other and the results are presented here.

\section{Uranium Occurrence}

The major types of Uranium deposits are grouped according to their respective geological setting however not in order of their economic potential [24-27]. Unconformity-related deposits occur in the immediate vicinity of major unconformities separating igneous basement and overlying clastic sediments. Metasediments near the boundary are usually faulted and brecciated and are the locus of the main mineralization. Igneous environments (intrusive and extrusive) not only include intrusive rocks per se, but vein deposits (graniterelated; fillings of voids, such as cracks, veins, fissures, pore spaces, breccias, and stock works), pegmatites containing rare metals ( $\mathrm{Sn}$, $\mathrm{Ta}, \mathrm{Nb}, \mathrm{Li}$, and REEs), volcanic and caldera-related deposits (forming veins or disseminations in acid to intermediate rocks related to faults and shear zones) and hematite breccia complex deposits (associated with a near surface explosive events involving boiling processes).

In metamorphic deposits, the uranium enrichment can directly derive and concentrate from the metamorphosed rock, while metasomatic processes (e.g., $\mathrm{Na}$ metasomatism) lead to a redistribution of uranium via leaching, transport, and mineralisation in the form of disseminations within structurally deformed rocks (Precambrian shields). With the exception of phosphorites (marine and of continental-shelf origin), sedimentary uranium deposits show the significance of carbon (coal and hydrocarbons; producing a reducing environment) in capturing uranium by adsorbing it on lignite (coal), organic matter in black shales (also carbonaceous pyritic shales), sandstone deposits. While the geological environment of some Archaean to early Palaeoproterozoic quartz pebble conglomerate deposits with detrital uraninite could also be classified as metamorphic environments, they also clearly indicate reducing conditions (anoxic atmosphere, prevalence of hydrocarbons at least during overprinting) in addition, hydrocarbons occasionally also enrich uranium.
Two-thirds of the world's production of uranium comes from Kazakhstan, Canada and Australia which mostly comes from Proterozoic rocks [28]. The Athabasca basin (Canada) accounts for $30 \%$ of high grade uranium production in the world [29]. The surface of the basin consists of main sandstone sediment varying from 100 to 1000 meters in depth. The uranium ore is mostly found at the base of this sandstone, at the point where it meets the basement [29]. In Australia, Queensland is the largest producer of uranium (as yellowcake) [30]. Kazakhstan has been an important source of uranium for more than 50 years [31]. New investigation to evaluate uranium contents occurring in India, Uzbekistan and many countries around the world. Jordan is the only country in the Middle East that has a confirmed source of Uranium [32].

The history of uranium exploration began during early 1980s in Sultanate of Oman, wherein [33-35] a number of target areas have been identified. Subsequently, a couple of sites were selected on the basis of prevailing radiation which prompted further investigation based on geophysical and geochemical methods. Accordingly, the Gamma ray spectroscopic investigation was carried out to trace the uranium concentration. Subsequently, a detailed study based on VLFEM technique has been carried out. According to Forbes et al. [36], in southwestern of Oman (some $300 \mathrm{~km}$ west of the site), there are indications of high radiation in oil well logs which intersecting the shales of the Andhur formation. The carbon content of these shales could have acted as a pre-concentrating medium for uranium while faults intersecting such formations acted as pathways for migrating fluids [36].

\section{Geology of the Study Area}

The study area covers an area of 0.35 sq.km (Dhofar region) encompasses the coordinates of latitudes $16.8847018 \mathrm{~N}$ to $16.89321 \mathrm{~N}$ and longitudes 53.4178125E to 53.4229073 E (Figure 1(a)). In this study, we focus on relatively young sub-horizontal layers of Tertiary micritic (EOzl) and lacustrine (Oaq) limestones including calcretes (surficial deposits) that are cross-cut by mineralised fault systems (veins). Geological map and vertical profile (the green arrow indicates the approximate position of the investigated site; the yellow line on the map corresponds to the location of the profile) in Figure 1(c), modified after the geological map of Oman, west of Salalah.

The area is heavily faulted (striking NE-SW, Figure 1(c)) and some of these faults have already been identified as the place of uranium enrichment. Since many of the limestone samples of the area have uranium levels below the detection limit of our equipment (portable XRF: $<1 \mathrm{ppm}$ ), we can rule out a general unfocussed uranium enrichment of the rocks. Rather, the fault systems must have acted as fluid conduits for circulating waters scooping up uranium from deeper formations and carrying it to higher levels along the fault plane and also distributing it near the surface. Possible sources for the observed uranium anomalies are: crystalline Proterozoic basement of the Arabian-Nubian Shield outcropping west of Salalah [37] igneous continental basement and carbonaceous shales, which appear in the underlying Andhur formation (Edm1; Figure 1(c) and Table 1) occur much higher up in the section.

\section{Data Acquisition and Interpretation}

A gamma ray spectrometer BGO Super RS-230 was used to acquire random sampling in addition to measurements along the traverses in order to record the uranium concentration in the area of study and is 
Citation: Sundararajan N, Pracejus B , Al- Khirbash S, Al- Hosni TK, Ebrahimi A, et al. (2017) Magnetic Mapping for Delineating Structures Favorable to Uranium Mineralization in Dhofar Region, Sultanate of Oman. Int J Earth Environ Sci 2: 127. doi: https://doi.org/10.15344/2456-351X/2017/127
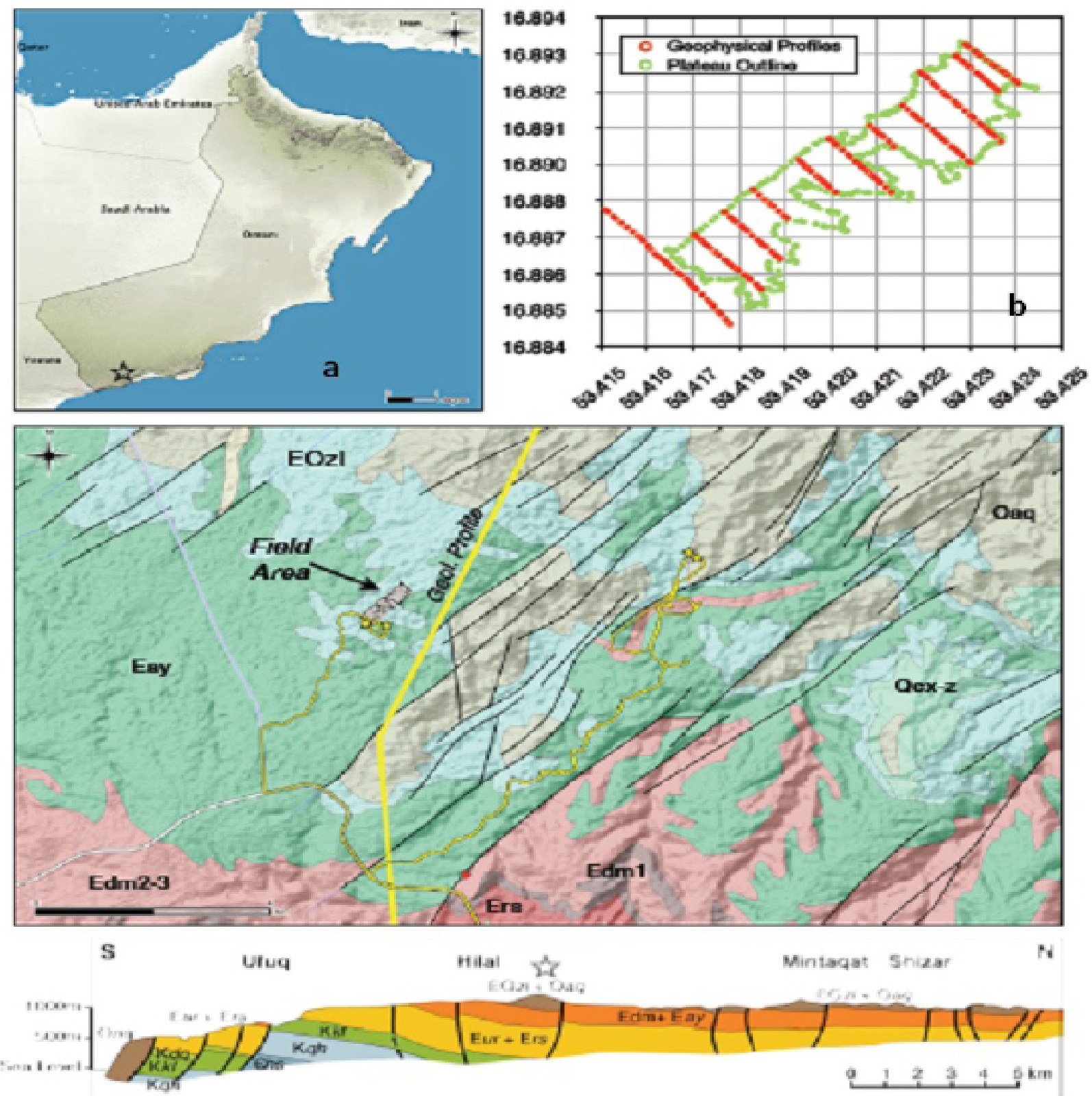

\section{C}

Figure 1: (a) Location of area of study (b) Geological map and vertical profile (courtesy Ministry of Commerce and Industry, 2013) and (c) Total magnetic field traverses in the field.

\begin{tabular}{|l|l|l|l|l|}
\hline Label & Age $(\mathrm{ma})$ & Stratigraphic Unit & Formation & Description \\
\hline Qcx-z & 24 & Quaternary & $/$ & slope colluvium \\
\hline EOzl & 92 & Tertiary & Zalumah & micritic limestones \\
\hline Oaq & 94 & Tertiary & Ashawq & lacustrine limestones \\
\hline Eay & 105 & Tertiary & Aydim & bioclastic limestones \\
\hline Edm2-3 & 110 & Tertiary & Dammam & bioclastic limestones \\
\hline Edm1 & 113 & Tertiary & Andhur & shale and intercalated limestones \\
\hline Ers & 120 & Tertiary & Rus & chalky dolomitic limestone and marl \\
\hline
\end{tabular}

Table 1: Overview of the geological rock units of the research area. 
Citation: Sundararajan N, Pracejus B , Al- Khirbash S, Al- Hosni TK, Ebrahimi A, et al. (2017) Magnetic Mapping for Delineating Structures Favorable to Uranium Mineralization in Dhofar Region, Sultanate of Oman. Int J Earth Environ Sci 2: 127. doi: https://doi.org/10.15344/2456-351X/2017/127

Page 4 of 9

shown in the form of contour image (Figure 2). Further, a G-859 mining magnetometer (Geomtrics) which is a high sensitive and rapid coverage device was employed to record the total magnetic field along eleven traverses of $20 \mathrm{~m}$ apart at a measurement interval of $10 \mathrm{~m}$ (Figure 1(b)). Followed by preliminary corrections, the contour map of the total magnetic intensity was prepared and shown in Figure 3. The corrected total intensity magnetic field was subjected to regionalresidual separation and the resulted regional (Figure 4a) and residual (Figure $4 \mathrm{~b}$ ) magnetic contour images are shown to clarify more details. Further, the amplitude of the analytical signal of the residual magnetic data was computed and shown in Figure 5. It may be noted here that the analytical signal aids in precise spatial location of the subsurface sources where it attains its maximum. The tilt derivative map has also been generated for fair estimation of depth as well as to ensure the nature of the subsurface source (Figure 6).

Source location as well as depth from magnetic data can fairly be estimated by the well known method of Euler deconvolution (ED) which has been computed and shown in Figure 7(a), assuming the structural index to be 0.5 corresponding to a contact. On the other hand, a structural index of 1 corresponding to a dyke resembles as shown in Figure 7(b). It may be mentioned here that the main difficulty in the method of (ED) is the choice of the correct structural index (SI) which plays a critical role for a meaningful estimation of the depth.Finally, the depth was estimated based on the well known Fourier spectral analysis of total magnetic intensity and shown in Figure 8 . The manually derived lineaments from the tilt magnetic map are shown in Figure 9(a) and the location map with lineaments is shown in Figure 9(b).

\section{Results and Discussion}

Raw magnetic data in Figure 3 shows high magnetic values along traverses L0, L5 and L10 indicating elevated level of mineralization. The regional (long wavelength deep seated features) magnetic map (Figure $4(\mathrm{a})$ ) in this area probably reflects the structure of the crystalline Proterozoic basement of the Arabian-Nubian Shield outcropping without significant contamination from shallower sources. In traverse L0, the pink area reflects deeper sources whereas red spots along traverses L4 to L10represent relatively shallower sources. The residual ground magnetic map of the study area (short wave length to depict shallow features) yields moderately low magnetic values as shown in Figure 4(b) corresponding to sources at shallow depth. Traverses L7 to L10 show magnetic anomaly with an elevated level in addition to negative anomaly which has been recorded along traverses L0 to L2. The amplitude of the analytical signal is shown in Figure 5 which aids in the precise spatial location of possible sources besides delineating boundaries of geologic structures along traverses L0 to L3, L4 to L7 and L8 to L10 respectively. The depth estimated by the method of ED from tilt derivative map (Figure 6) indicates the depth to the sources at different depths varying from less than $15 \mathrm{~m}$ to greater than 45 $\mathrm{m}$ along different traverses. Similarly, the Euler deconvolution (ED) for the structural indices of 0.5 and 1.0 corresponding to contact and dyke respectively results depths in the range $<15 \mathrm{~m}->45 \mathrm{~m}$ and $<20 \mathrm{~m}->60 \mathrm{~m}$. However, the radial spectrum yields a depth around $64 \mathrm{~m}$ which fairly agrees with the depth obtained from ED. The depths obtained from various interpretative tools are compared and shown in Table 2. Computed tilt derivative of the structural map and the manually derived lineaments are possibly mineralized ones and are shown in Figure 9(a) and Figure 9(b), respectively.

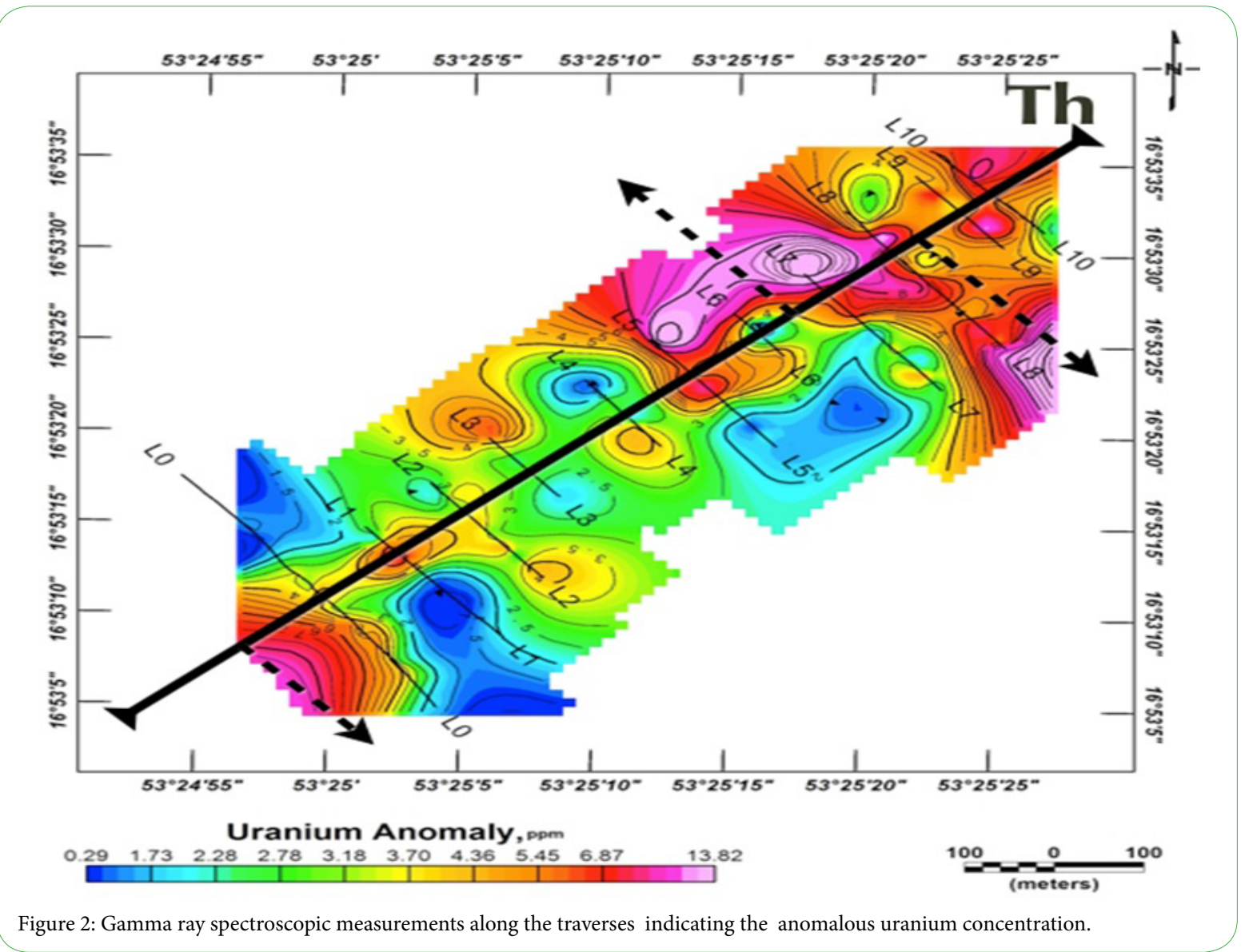

Int J Earth Environ Sci 
Citation: Sundararajan N, Pracejus B , Al- Khirbash S, Al- Hosni TK, Ebrahimi A, et al. (2017) Magnetic Mapping for Delineating Structures Favorable to Uranium Mineralization in Dhofar Region, Sultanate of Oman. Int J Earth Environ Sci 2: 127. doi: https://doi.org/10.15344/2456-351X/2017/127

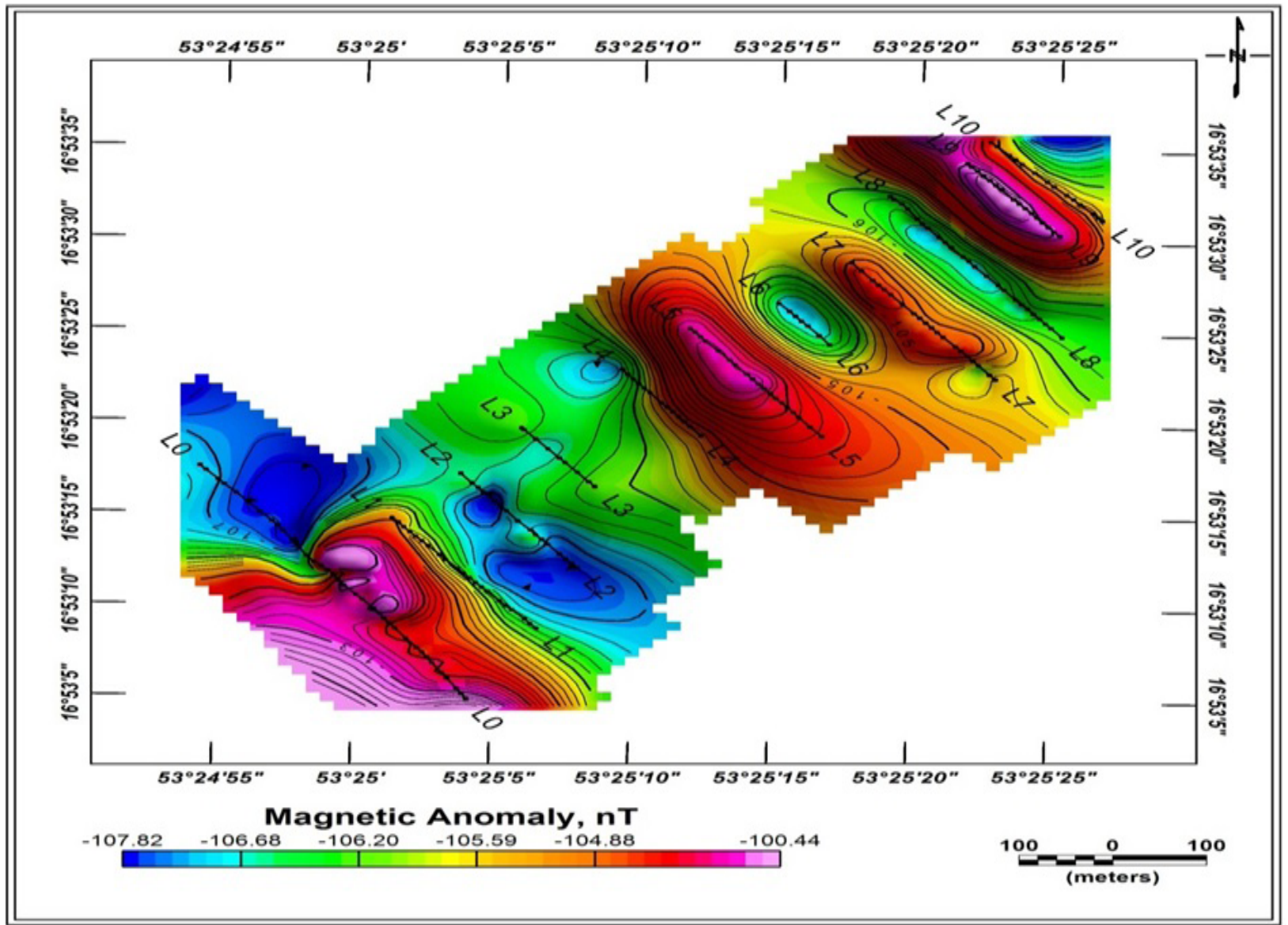

Figure 3: Contour image of the raw total magnetic field.
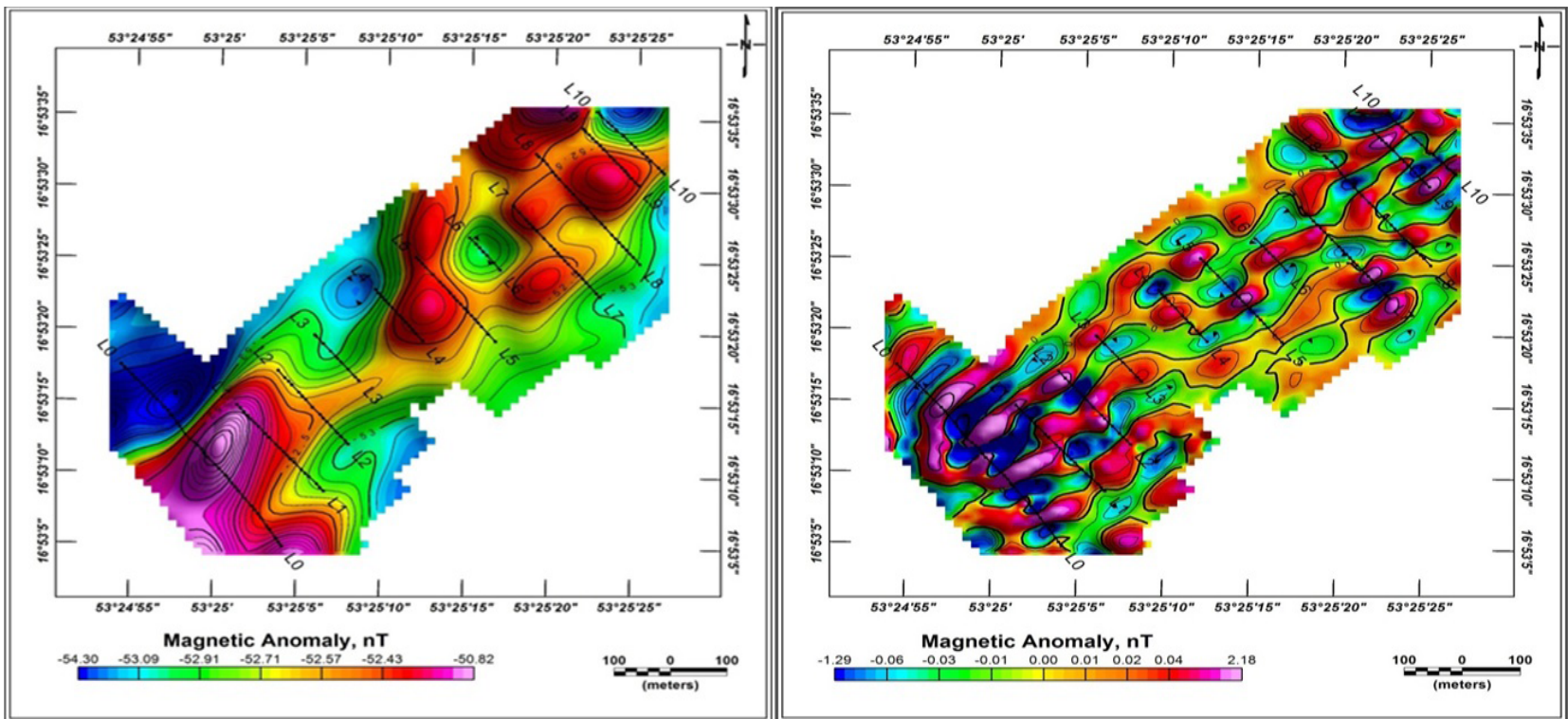

Figure 4: (a) Regional and (b) Residual component of magnetic field data. 
Citation: Sundararajan N, Pracejus B , Al- Khirbash S, Al- Hosni TK, Ebrahimi A, et al. (2017) Magnetic Mapping for Delineating Structures Favorable to Uranium Mineralization in Dhofar Region, Sultanate of Oman. Int J Earth Environ Sci 2: 127. doi: https://doi.org/10.15344/2456-351X/2017/127

Page 6 of 9

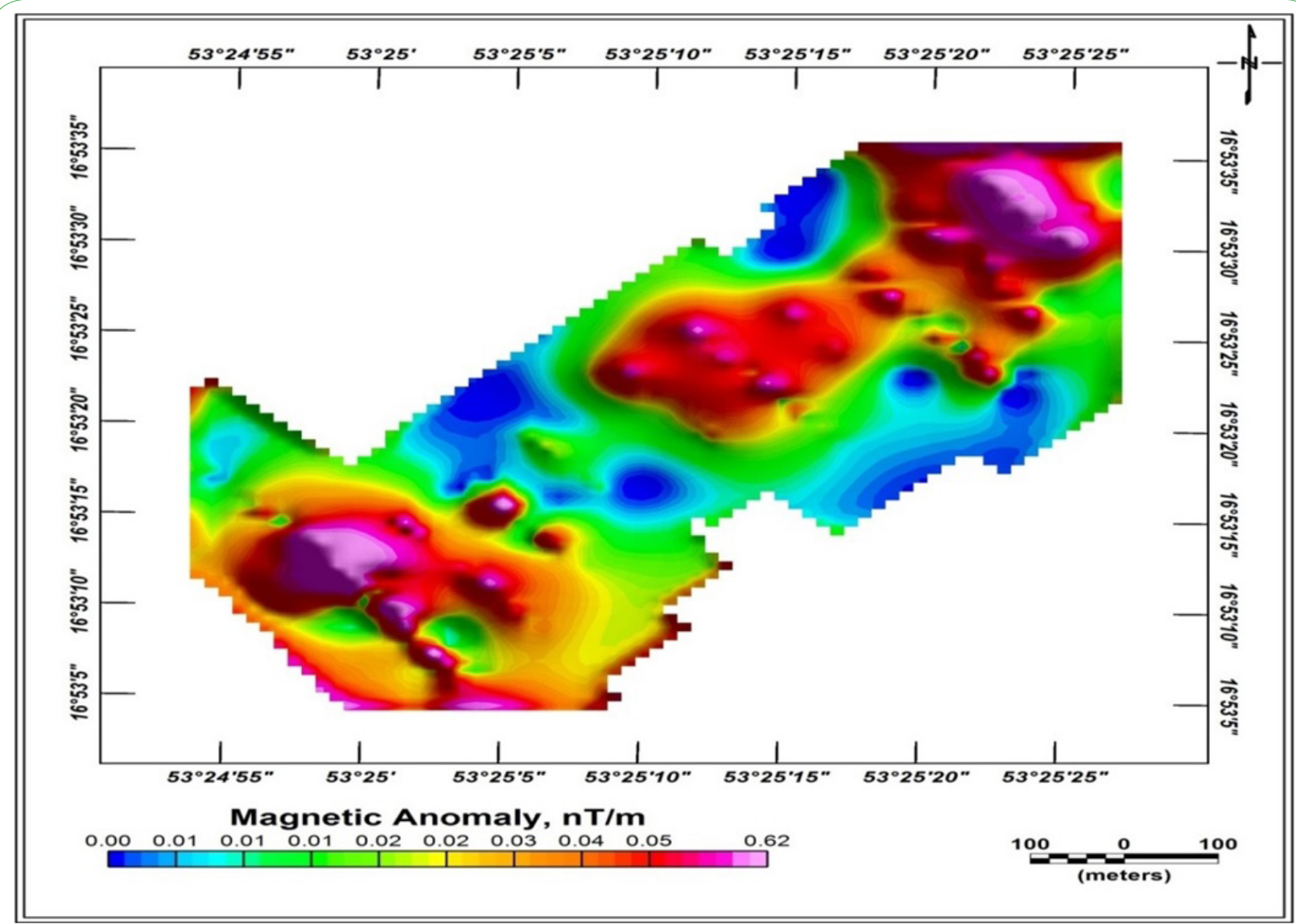

Figure 5: Amplitude of analytic signal of the total magnetic field.

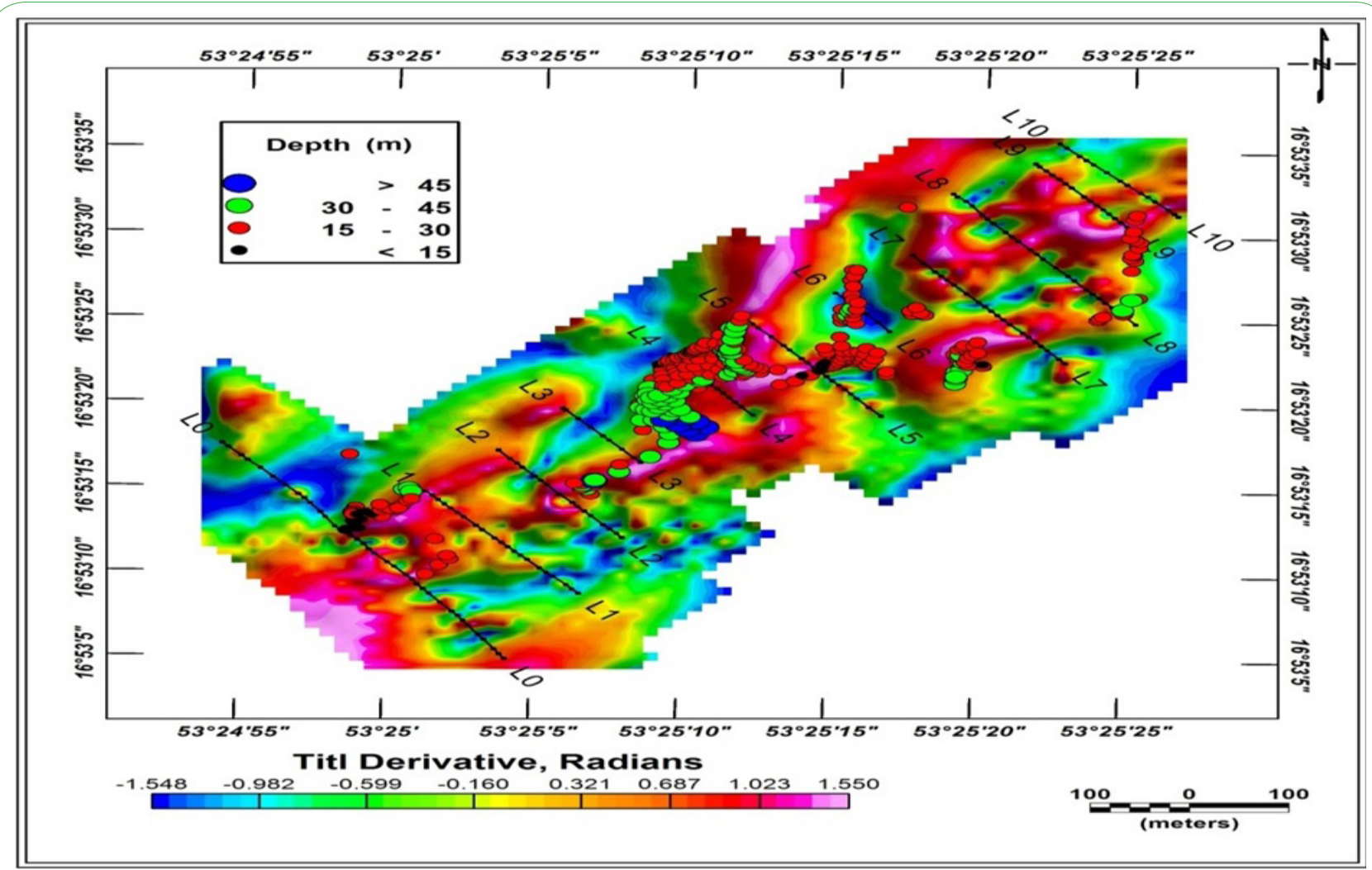

Figure 6: Euler deconvolution of tilt derivative map of the total magnetic field.

Int J Earth Environ Sci

ISSN: 2456-351X
IJEES, an open access journal Volume 1.2017. 127 
Citation: Sundararajan N, Pracejus B , Al- Khirbash S, Al- Hosni TK, Ebrahimi A, et al. (2017) Magnetic Mapping for Delineating Structures Favorable to

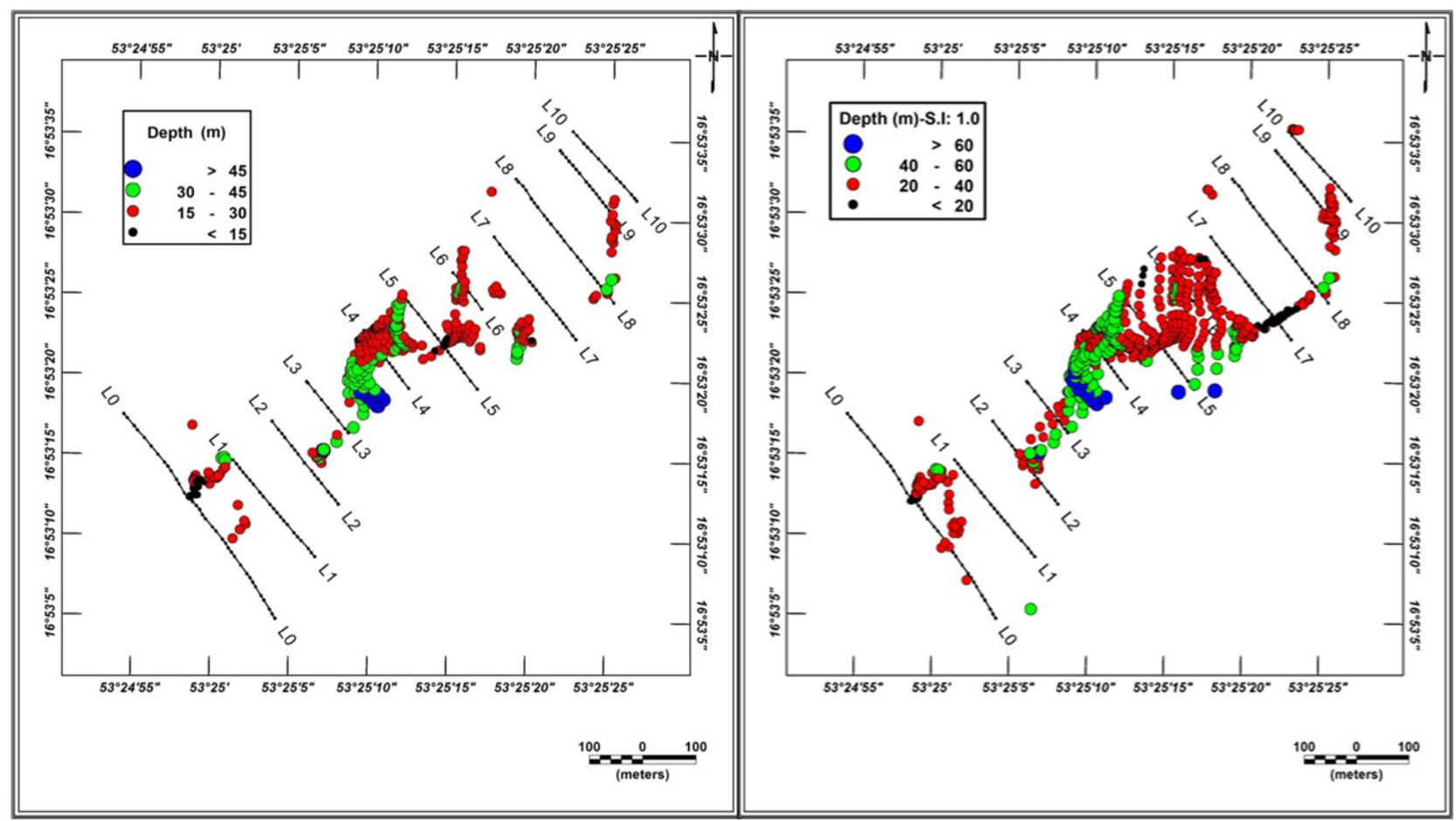

Figure 7: Euler deconvolution under the assumption of (a) a contact with structural index 0.5and (b) a dyke with structural index 1.0.

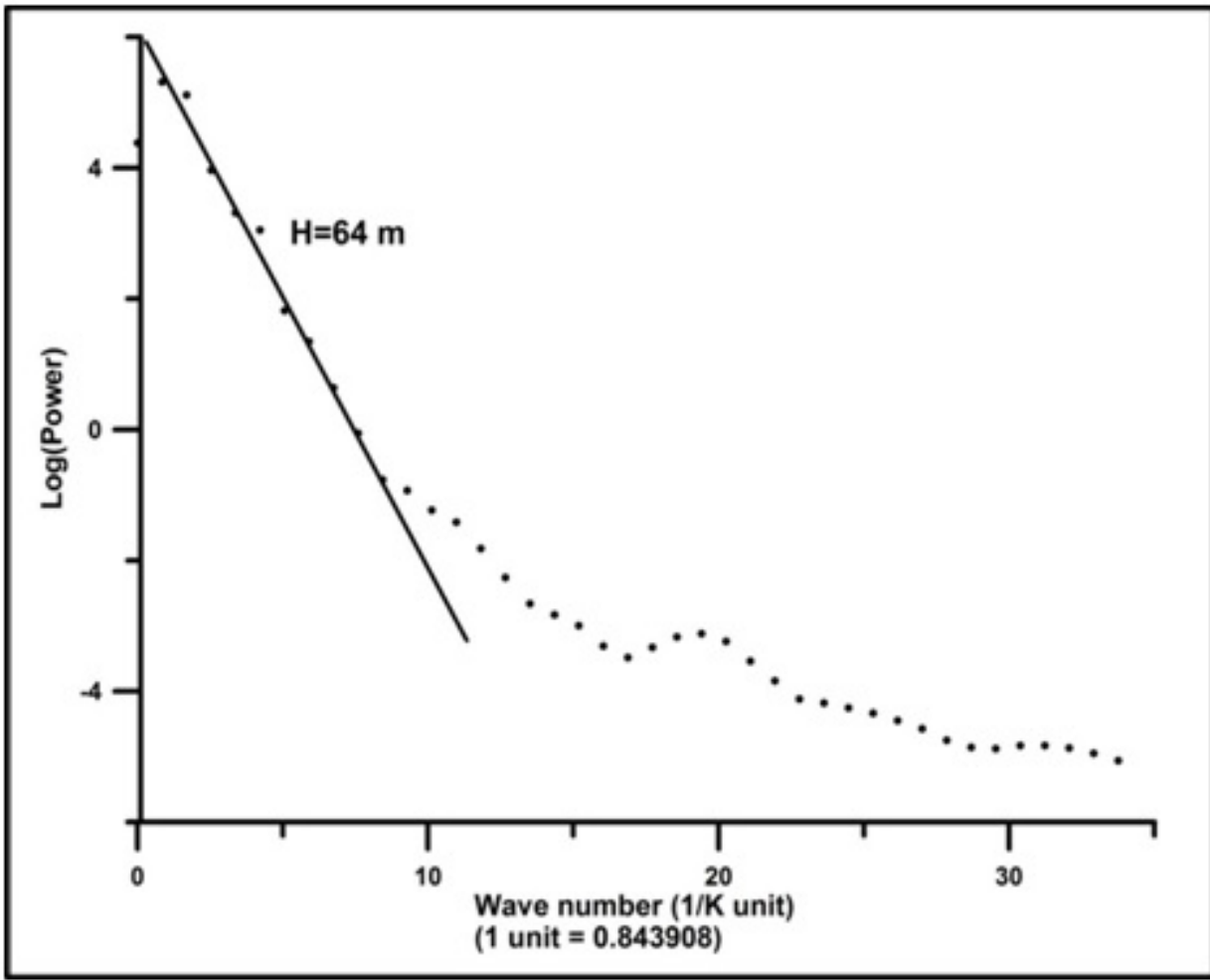

Figure 8: Fourier spectral analysis of the residual magnetic data. 
Citation: Sundararajan N, Pracejus B , Al- Khirbash S, Al- Hosni TK, Ebrahimi A, et al. (2017) Magnetic Mapping for Delineating Structures Favorable to Uranium Mineralization in Dhofar Region, Sultanate of Oman. Int J Earth Environ Sci 2: 127. doi: https://doi.org/10.15344/2456-351X/2017/127

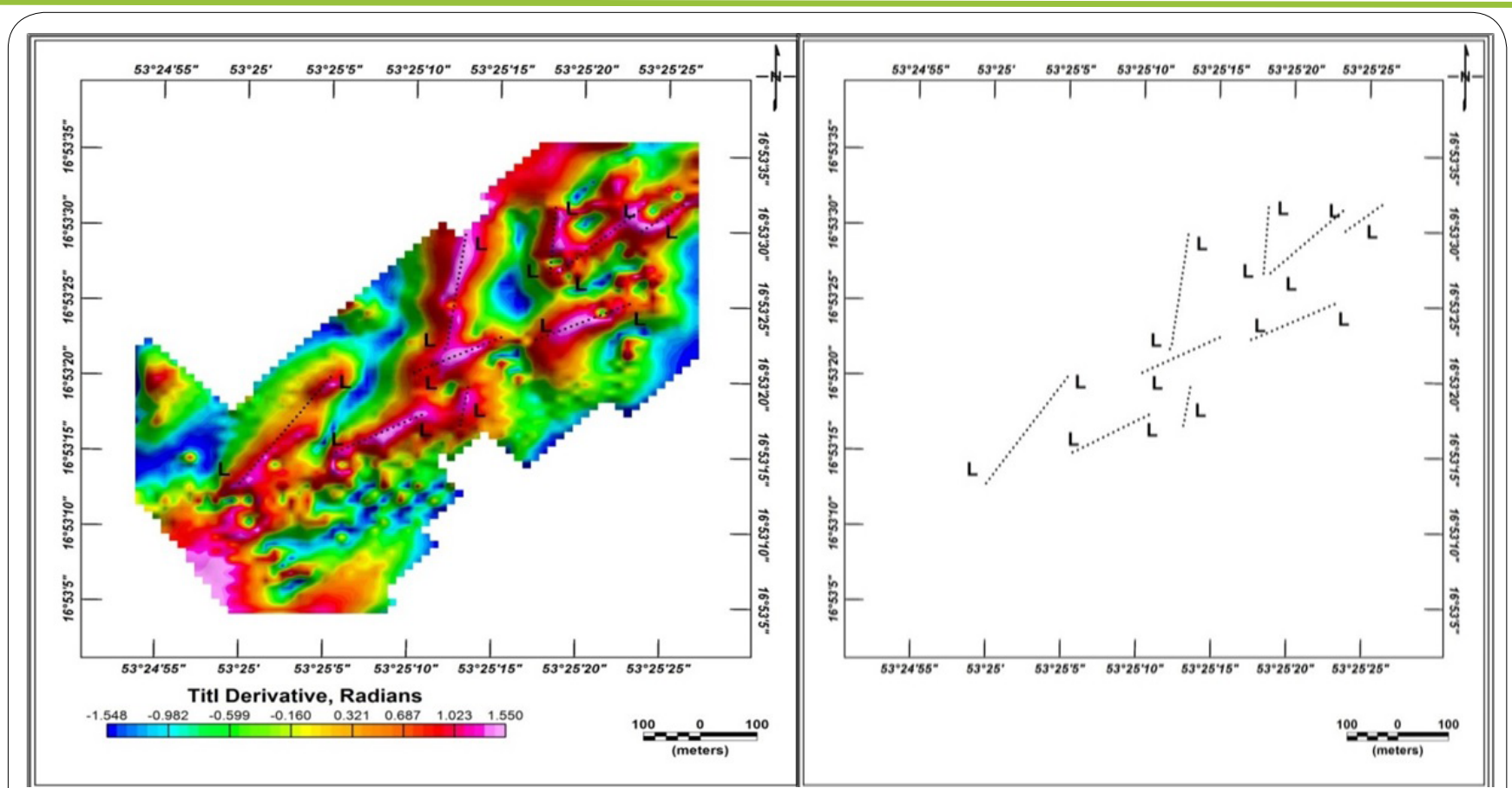

Figure 3: Manually derived structures (a) from the tilt derivative map and (b) the manually derived lineaments shown in the geographic location map.

\begin{tabular}{|r|r|c|c|}
\hline Methods & Tilt derivative & Euler decon & Spectral analysis \\
\hline Depths in $\mathrm{m}$ & $45<-15>$ & $60<-20>$ & 64 \\
\hline
\end{tabular}

Table 2: Depth to subsurface structure by various methods of interpretation.

\section{Conclusions}

Reported gamma ray spectroscopic recordings although indicates a moderate radioactivity in the study area, it may highly likely that the radioactive mineralization is deeply seated. It is apparent that the structures favorable in this case are the subsurface fault/ lineaments as deep as $60 \mathrm{~m}$ may substantiate the possible mineralization. From the total regional and residual magnetic maps, anomalous structures may strongly be realized along traverses L0 to L3 and L7 to L10. Further, the mineralized structures/lineaments possibly be as deep as less than $15 \mathrm{~m}$ to greater than $60 \mathrm{~m}$ as evidenced by different interpretation tools like title derivative, Euler deconvolution and spectral analysis substantiated by their precise location from amplitude of analytical signal.

\section{Acknowledgements}

The authors wish to record their sincere thanks to Sultan Qabbos University for the strategic grants provided to support this investigation.

\section{Competing Interests}

The authors declare that they have no competing interests.

\section{References}

1. Supper R, Baron I, Ottowitz D, Motschka K, Gruber S, et al. (2013) Airborne geophysical mapping as an innovative methodology for landslide investigation: evaluation of results from the Gschliefgraben landslide, Austria. Nat Hazards Earth Sys Sci 13: 3313-3328.
2. Waswa AK, Nyamai CM, Mathu E, Ichang'i DW (2015) Application of magnetic survey in the investigation of iron ore deposits and shear zone delineation: case study of Mutomo-lkutha area, SE Kenya. Int J Geosci 6: 729 .

3. Chakravarthi V, Shankar GBK, Muralidharan D, Harinarayana T, Sundararajan N (2007) An integrated geophysical approach for imaging subbasalt sedimentary basins: case study of Jam River Basin, India. Geophy 72: B141-B147.

4. Chary MN, Srinivas Y, Sundararajan N (2005) Structural analysis of magnetic anomalies across Gondwana Outlier near Tiruvuru, Krishna District, Andhra Pradesh. J Ind Geophys 9: 21-28.

5. Demeshko S, Leibeling G, Maringgele W, Meyer F, Mennerich C, et al. (2005) Structural Variety and Magnetic Properties of Tetranuclear Nickel (II) Complexes with a Central $\mu 4-A z i d e$. Inorganic chem 44: 519-528.

6. Portal A, Gailler LS, Lénat JF, Labzuy P (2015) Internal structure of a complex lava dome and of its surrounding inferred from gravity and magnetic data. In EGU General Assembly Conf Abstracts 173847.

7. Likkason OK, Singh GP, Samaila NK (2013) A Study of the Middle Benue Trough (Nigeria) Based on Geological Application and Analyses of Spectra of Aeromagnetic Data. Energ Source Part A: Recovery Utilization Environmental Effect 35: 706-716.

8. Ramesh Babu V, Ram S, Sundararajan N (2007) Modeling and inversion of magnetic and VLF-EM data with an application to basement fractures: A case study from Raigarh, India. Geophy 72: B133-B140.

9. Peters LJ (1949) The direct approach to magnetic interpretation and its practical application. Geophy 14: 290-320.

10. Al-Garni MA (2010) Magnetic survey for delineating subsurface structures and estimating magnetic sources depth, Wadi Fatima, KSA. J King Saud University-Sci 22: 87-96.

11. Verduzco B, Fairhead JD, Green CM, MacKenzie C (2004) New insights into magnetic derivatives for structural mapping. The Lead Edge 23:116119

12. Nettleton LL (1962) Gravity and magnetics for geologists and seismologists AAPG Bulletin 46: 1815-1838.

13. Li Y, Oldenburg DW (1998) Separation of regional and residual magnetic field data. Geophy 63: 431-439.

14. Thompson DT (1982) EULDPH: A new technique for making computerassisted depth estimates from magnetic data. Geophysics 7: 31-37. 
Citation: Sundararajan N, Pracejus B , Al- Khirbash S, Al- Hosni TK, Ebrahimi A, et al. (2017) Magnetic Mapping for Delineating Structures Favorable to Uranium Mineralization in Dhofar Region, Sultanate of Oman. Int J Earth Environ Sci 2: 127. doi: https://doi.org/10.15344/2456-351X/2017/127

Page 9 of 9

15. Reid AB, Allsop JM, Granser H, Millett AT, Somerton IW (1990) Magnetic interpretation in three dimensions using Euler deconvolution. Geophy 55 $80-91$.

16. Telford WM, Geldart LP, Sheriff RE (1990) Applied geophysics. Cambridge university press.

17. Spector A, Grant FS (1970) Statistical models for interpreting aeromagnetic data. Geophy 35: 293-302.

18. Salem A, Williams S, Fairhead JD, Ravat D, Smith R (2007) Tilt-depth method: A simple depth estimation method using first-order magnetic derivatives. The Lead Edge 26: 1502-1505.

19. Thurston JB, Smith RS (1997) Automatic conversion of magnetic data to depth, dip, and susceptibility contrast using the SPI (TM) method. Geophysics 62: 807-813.

20. Nabighian MN (1972) The analytic signal of two-dimensional magnetic bodies with polygonal cross-section: Its properties and use for automated anomaly interpretation. Geophy 37 507-517.

21. Roest WR, Verhoef J, Pilkington M (1992) Magnetic interpretation using the 3-D analytic signal. Geophy 57: 116-125

22. Keating $P$, Sailhac $P(2004)$ Use of the analytic signal to identify magnetic anomalies due to kimberlite pipes. Geophy 69: 180-190.

23. Sundararajan N, Rao PS, Sunitha $V$ (1998) An analytical method to interpret self-potential anomalies caused by $2-D$ inclined sheets. Geophy 63: 1551-1555

24. Toens PD, and Hambleton-Jones BB (1984) Definition and classification of surficial uranium deposits. Int Atomic Energy Agency 252: 9-14.

25. Adler HH (1974) Concepts of uranium-ore formation in reducing environments in sandstones and other sediments. Format Uranium ore deposit 141-168

26. Poty B, Leroy J, Cathelineau M, Cuney M, Friedrich M, et al. (1986) Uranium deposits spatially related to granites in the French part of the Hercynian orogen. Int Atomic Energy Agency 423: 215-246

27. Fralick PW, Miall AD (1989) Sedimentology of the Lower Huronian Supergroup (Early Proterozoic), Elliot Lake area, Ontario, Canada. Sediment Geology 63: 127-153.

28. Guang $Y$, Wenjie $H$ (2010) The status quo of China's nuclear power and the uranium gap solution. Energ Policy 38: 966-975

29. Jefferson CW, Thomas DJ, Gandhi SS, Ramaekers P, Delaney G, et al (2007) Unconformity-associated uranium deposits of the Athabasca Basin, Saskatchewan and Alberta. Bulletin-Geolog Survey of Canada 5: 273-305.

30. Brooks JH (1972) Uranium exploration in Queensland. Geological Survey of Queensland, Report 69: 6-8.

31. Castro JM, Moore JN (2000) Pit lakes: their characteristics and the potential for their remediation. Environ Geology 39:1254-1260.

32. Abusini M, Al-Ayasreh K, Al-Jundi J (2008) Determination of uranium, thorium and potassium activity concentrations in soil cores in Araba valley, Jordan. Radiat protect dosimetry 128: 213-216.

33. Quidwai H (1981) Wadi Gharbatan uranium prospect - Final report, Ministry of Petroleum and Minerals.

34. Quidwai H, Khalifa M (1982) Ground follow-up of the airborne radiometric anomalies in south western Dhofar, Sultanate of Oman: Ministry of Petroleum and Minerals.

35. BRGM (1984) Geological study of the mineral occurrence of the central part of the Northern Oman mountains (Unpublished report). 2- 289.

36. Forbes GA, Jansen HSM, Schreurs J (2010) Lexicon of Oman Subsurface Stratigraphy: GeoArabia Special Publication. Gulf Petrolink 5: 371.

37. Mercolli I, Briner AP, Frei R, Schönberg R, Nägler TF, et al. (2006) Lithostratigraphy and geochronology of the Neoproterozoic crystalline basement of Salalah, Dhofar, Sultanate of Oman. Precambrian Res 145 182-206. 